\title{
EWOLUCJA PRAWA WYBORCZEGO DO SENATU W III RP
}

\section{Założenia wstępne}

Biorąc pod uwagę sposób wykonywania władzy przez suwerena, możemy wyodrębnić dwie podstawowe formy demokracji, tj. demokrację bezpośrednią i przedstawicielską (pośrednią). ${ }^{1} \mathrm{~W}$ przypadku demokracji bezpośredniej obywatele samodzielnie podejmują decyzje (ewentualnie wyrażają opinie), natomiast istotą demokracji przedstawicielskiej jest wybór reprezentantów, którzy w imieniu suwerena rozstrzygają konkretne sprawy. We współczesnym świecie $-\mathrm{z}$ uwagi na rozległość terytorialną państw i dużą liczbę obywateli - demokracje mają charakter przedstawicielski. Jak zaznaczył R. Legutko, „obecnie mamy do czynienia z demokracjami pośrednimi, wobec tego obywatele są utrzymywani z daleka od centrów decyzyjnych". ${ }^{2}$ Mając na uwadze zasygnalizowane uwarunkowania należy podkreślić, iż dla obywateli współczesnych państw demokratycznych wybory stanowią niezwykle istotny instrument wywierania wpływu na funkcjonowanie systemu politycznego. Dzięki przedmiotowej procedurze suweren raz na kilka lat uzyskuje realny wpływ na politykę i ma faktyczną władzę nad elitami politycznymi. Jan Jakub Rousseau wyraził w tym kontekście dość skrajny pogląd, podkreślając iż „lud angielski sądzi, że jest wolny, lecz myli się bardzo; jest wolny tylko podczas wyborów członków parlamentu; skoro tylko zostali oni wybrani, staje się niewolnikiem, staje się niczym". ${ }^{3}$

W kontekście funkcjonowania współczesnych demokracji należy pamiętać, iż możliwości oddziaływania obywateli na system polityczny nie kończą się na wyborach, gdyż występuje chociażby kilka instytucji demokracji bezpośredniej, takich jak: zgromadzenie ludowe, referendum, plebiscyt, inicjatywa ludowa, weto ludowe, konsultacje społeczne, jak również intensywnie rozwijający się w ostatnich latach (także w Polsce) budżet partycypacyjny (obywatelski). Jednakże słabością aktualnie

Zob. szerzej: P. Uziębło, Demokracja partycypacyjna. Wprowadzenie, Gdańsk 2009, s. 13-19.

R. Legutko, Problemy demokratycznej partycypacji, (w:) J. Miklaszewska (red.), Polityka i świat wartości. Uczestnictwo obywateli w życiu społeczno-politycznym, Kraków 1998, s. 34.

3 J.J. Rousseau, Umowa społeczna, Warszawa 1966, s. 112-113. 
występujących form demokracji bezpośredniej jest fakt, iż zazwyczaj pozostają one pod kontrolą elit politycznych. ${ }^{4}$ Dlatego też o ich zastosowaniu nie decydują obywatele, lecz przedstawiciele (np. parlamentarzyści).

Jak trafnie podkreślił G. Bingham Powell, Jr., „Wybory nie są jedynymi narzędziami demokracji. Muszą je wspierać organizacje i reguły zachęcające do porozumienia i współpracy. Wybory wydają się jednak kluczowym instrumentem demokracji, który ma tworzyć powiązania zmuszające lub silnie zachęcające polityków do liczenia się z obywatelami. Panuje powszechna zgoda co do tego, że wybory oparte na zasadzie rywalizacji politycznej, bardziej niż cokolwiek innego, przesądzają dziś o demokratycznym charakterze systemu politycznego państwa narodowego". ${ }^{5}$

Procedury wyborcze przyciągają uwagę elit politycznych, dla których jest to rywalizacja o władzę i możliwość realizacji własnego programu wyborczego, jak również obywateli i środków masowego przekazu. W tym miejscu należy podkreślić, iż wybory mogą być przeprowadzane według różnych zasad, co w istotny sposób wpływa na ich ostateczny wynik. Dlatego też elity polityczne, a w szczególności partie polityczne mające odpowiednią większość w parlamencie starają się tak ukształtować system wyborczy, aby był odpowiedni z punktu widzenia ich interesów. Jak zaakcentował Z. Jackiewicz, ,analizując zmiany w prawie wyborczym oraz przebieg i wyniki kolejnych wyborów, znajdujemy wiele danych świadczących o tym, że polski prawodawca odgrywa $\mathrm{w}$ dziedzinie wyborów szczególną rolę: jest nie tylko twórcą reguł prawnych, zgodnie z którymi toczą się wybory, ale również podmiotem współdecydującym o wynikach wyborów". ${ }^{6}$

Celem artykułu było przedstawienie ewolucji prawa wyborczego do Senatu w III RP (1989-2011). Szczególne miejsce w rozważaniach zajęła kwestia formuły wyborczej stosowanej w wyborach do tej izby polskiego parlamentu. Na potrzeby niniejszego szkicu przyjęto założenie, iż formuła wyborcza oznacza zasadę przekształcania głosów wyborców na mandaty. ${ }^{7}$ Ponadto zwrócono uwagę na zagadnienie wyborów uzupełniających do Senatu.

W omawianym okresie wybory do Senatu odbywały się według formuły większościowej, jednakże dopiero od roku 2011 obowiązują okręgi jednomandatowe (wcześniej stosowano okręgi kilkumandatowe). Co istotne, od 1991 roku zdobycie mandatu senatora było uzależnione od uzyskania większości względnej. W tym miejscu nasuwa się pytanie o wpływ przyjętej formuły wyborczej na skład „drugiej giczny" 2010, $\mathrm{nr}$ 1, s. 103-114.

5 G. Bingham Powell, Jr., Wybory jako narzędzie demokracji. Koncepcje większościowe i proporcjonalne, Warszawa 2006, s. 8.

$6 \quad$ Z. Jackiewicz, Wpływ prawodawcy na wyniki wyborów, „Państwo i Prawo” 1995, z. 3, s. 44.

7 W niektórych opracowaniach formułę wyborczą określa się również ogólną nazwą „system wyborczy”. W niniejszym artykule dokonano rozróżnienia zgodnie z treścią hasła „system wyborczy” w publikacji „Leksykon politologii”. Zob. szerzej: R. Herbut, System wyborczy, (w:) A. Antoszewski, R. Herbut (red.), Leksykon politologii, Wrocław 2002, s. 441-444. 
izby" polskiego parlamentu. Biorąc pod uwagę doświadczenia innych państw przyjęto hipotezę, iż ustanowione rozwiązanie skutkowało zniekształceniem woli wyborców, tj. zwycięski komitet posiadał w Senacie znacznie większą reprezentację niż uzyskany wynik procentowy.

\section{Kilka uwag na temat formuły wyborczej}

Jak zaznaczył K. Polarczyk, w wyborach powszechnych i bezpośrednich ,stosowane są dwie podstawowe formuły wyborcze: większościowa i proporcjonalna, przy czym przy wyborze parlamentarzystów do określonej izby mogą być stosowane obie formuły, co oznacza, że część mandatów parlamentarnych izby jest obsadzana według zasady większości, a część według zasady proporcjonalności. Taka formuła jest określana jako mieszana. Najwcześniej stosowaną i do dziś przeważającą jest formuła większościowa. Formuła proporcjonalna po raz pierwszy została zastosowana w Belgii w 1889 roku". ${ }^{8}$ Tak więc w istocie możemy wyróżnić trzy podstawowe formuły wyborcze, tj. większościową, proporcjonalną i mieszaną, które nie mają jednolitego charakteru i występują w różnych wariantach.

W przypadku systemu większościowego mandat uzyskuje ten z kandydatów, który zdobędzie najwięcej głosów w okręgu jednomandatowym. System większościowy występuje w dwóch formach, tj. do zdobycia mandatu może wystarczyć większość względna (najwięcej głosów w okręgu) lub też należy uzyskać większość bezwzględną (ponad 50\% ważnie oddanych głosów w okręgu). Wybory przeprowadzane przy zastosowaniu większości względnej zawsze kończą się na I turze, jednakże to oznacza, iż zwycięski kandydat może cieszyć się poparciem mniejszości głosujących. Tym samym wybory przeprowadzane według wskazanej formuły są tańsze, aczkolwiek pewną słabością może być mniejsza legitymacja społeczna zwycięskiego kandydata. Z kolei przyjęcie większości bezwzględnej często wiąże się z koniecznością przeprowadzenia II tury wyborów, co występuje w sytuacji, gdy żaden $\mathrm{z}$ kandydatów podczas I tury nie otrzyma ponad 50\% głosów. W drugiej turze uprawnieni do głosowania wybierają spośród dwóch kandydatów, którzy uzyskali najwięcej głosów podczas pierwszej tury wyborów. W tym miejscu należy dodać, iż system większościowy może być również stosowany w okręgach wielomandatowych (kilkumandatowych). Wówczas ,wyborca posiada tyle głosów, ile mandatów jest do obsadzenia w danym okręgu. Za wybranych uważa się tych kandydatów, którzy uzyskali kolejno największe liczby głosów".

Istotą systemu proporcjonalnego jest to, aby liczba mandatów uzyskanych przez komitet wyborczy jak najbardziej odzwierciedlała odsetek głosów zgromadzonych

\footnotetext{
8 K. Polarczyk, Parlament polski na tle parlamentów innych państw. Analiza statystyczna, Raport nr 214 Biura Studiów i Ekspertyz Kancelarii Sejmu, Warszawa 2003, s. 42.

9 A. Antoszewski, R. Alberski, Systemy wyborcze, (w:) A. Antoszewski, R. Herbut (red.), Demokracje zachodnioeuropejskie. Analiza porównawcza, Wrocław 1997, s. 231.
} 
przez kandydatów danego komitetu. Jeśli zatem na partię X oddano $10 \%$ głosów, powinna ona uzyskać $10 \%$ mandatów. W praktyce jednak żadna $\mathrm{z}$ wersji formuły proporcjonalnej nie gwarantuje osiągnięcia takiego idealnego stanu, co w efekcie prowadzi do pewnej dysproporcji między wielkością poparcia społecznego a liczbą uzyskanych miejsc $\mathrm{w}$ kreowanym organie przedstawicielskim. ${ }^{10}$ Wielkość przedmiotowej różnicy jest uzależniona między innymi od przyjętej metody przeliczania głosów wyborców na mandaty. Należy podkreślić, iż stosowanie formuły proporcjonalnej wymaga, aby wyborcy oddawali głosy na listy partyjne, a w okręgu wybierana była większa liczba przedstawicieli. „Stosowane w praktyce metody proporcjonalnego podziału mandatów należą $\mathrm{w}$ większości do jednej z dwóch grup:

- metody oparte na stałej kwocie, jak metoda największych reszt Hamiltona-Hare'a-Niemayera;

- metody dzielnikowe (oparte na kwocie a posteriori), jak metoda Jeffersona-d'Hondta czy Webstera-Sainte-Laguë'. ${ }^{11}$

Z punktu widzenia przedmiotu niniejszego szkicu najważniejsze znaczenie ma formuła większościowa, gdyż wybory do Senatu w Polsce odbywają się zgodnie $\mathrm{z}$ tym rozwiązaniem. Dlatego też $\mathrm{w}$ dalszej części przedstawiono podstawowe zalety i wady przedmiotowej formuly wyborczej.

System większościowy w praktyce wyłącza $\mathrm{z}$ rywalizacji mniejsze ugrupowania. „Jest to system dostosowany do sytuacji, w której rywalizują ze sobą dwie silne, ogólnokrajowe partie polityczne, jak w Wielkiej Brytanii czy USA. Wówczas najpełniej ujawniają się jego zalety, z których główne sprowadzają się do stabilizacji sceny politycznej poprzez eliminację partii słabych oraz do wzmocnienia więzi między wyborcą a deputowanym. Ten pierwszy oddaje bowiem swój głos nie na abstrakcyjny program bądź ideologię, ale na konkretną osobę". ${ }^{12}$ Przytoczone zalety powodują znaczną popularność formuły większościowej w Polsce i wysuwanie postulatu, aby przyjąć takie rozwiązanie między innymi w wyborach do Sejmu. W badaniu przeprowadzonym w 2008 roku za wprowadzeniem jednomandatowych okręgów wyborczych opowiedziało się $64 \%$ badanych, a tylko jedna ósma (12\%) była przeciwna takiemu rozwiązaniu. ${ }^{13}$

System większości względnej wykazuje poważne wady w sytuacji, gdy w rywalizacji uczestniczy wiele partii politycznych (komitetów wyborczych). Wówczas może dojść do sytuacji, w której większość wyborców nie będzie reprezentowana $\mathrm{w}$ kreowanym organie przedstawicielskim. Dla zobrazowania wzmiankowanego mankamentu można przytoczyć przykład okręgu z pięcioma kandydatami, spośród

R. Herbut, System..., op. cit., s. 442.

J. Haman, Demokracja. Decyzje. Wybory, Warszawa 2003, s. 74.

A. Antoszewski, R. Alberski, Sytemy wyborcze..., op. cit., s. 231.

Dane przytoczono za: Centrum Badania Opinii Społecznej, Polacy o proponowanych zmianach w systemie politycznym. Komunikat z badań, Warszawa 2008. 
których zwycięzca otrzymał $21 \%$, trzech kolejnych po $20 \%$, natomiast ostatni kandydat $19 \%$ głosów. W opisanej sytuacji aż $79 \%$ wyborców nie będzie miało swojego przedstawiciela. „Jeśli efekt taki powtórzy się w większej liczbie okręgów, może dojść do tego, że rządy obejmie partia popierana przez mniejszość wyborców". ${ }^{14}$

\section{Ewolucja prawa wyborczego do Senatu}

Po II wojnie światowej utworzono w Polsce parlament jednoizbowy, co było efektem oficjalnych wyników referendum z 1946 roku. Dyskusje nad przywróceniem drugiej izby zapoczątkowano w latach osiemdziesiątych XX w., niemniej propozycja restytucji Senatu (zgłoszona w czasie obrad „Okrągłego Stołu”) wynikała raczej z potrzeb kompromisu politycznego niż z przemyśleń modelowych. ${ }^{15}$ Rozstrzygnięcia ostatecznie przyjęte przy „Okrągłym Stole” skutkowały przywróceniem Senatu do polskiego systemu politycznego. Podczas obrad strony rządowej z opozycją uzgodniono także zasady wyborów do obu izb parlamentu. W odniesieniu do Senatu znalazł się między innymi następujący zapis: „W wyborach do Senatu z każdego województwa wybiera się po 2 senatorów, a w województwie stołecznym i katowickim - po 3". ${ }^{16}$ Tak więc każde ówczesne województwo (49) było okręgiem wyborczym do tej izby parlamentu. W 47 okręgach (województwach) wybierano po dwóch senatorów, a w województwie warszawskim i katowickim - po trzech. Zasadniczo doprowadziło to do sytuacji, w której znacznie różniące się pod względem liczby mieszkańców województwa miały taką samą reprezentację w Senacie. W konsekwencji wybory do Senatu nie były równe w aspekcie materialnym. W tym miejscu warto przypomnieć, iż porozumienia zawarte przy „Okrągłym Stole” nadały Senatowi silną legitymację demokratyczną, gdyż inaczej niż Sejm, został on w 1989 roku wybrany w całkowicie wolnych wyborach. ${ }^{17}$

W aspekcie prawnym proces zasadniczej przebudowy ustrojowej został rozpoczęty w dniu 7 kwietnia 1989 roku gruntowną zmianą Konstytucji PRL-u. ${ }^{18}$ Przedmiot tej nowelizacji ${ }^{19}$ odzwierciedlał treść porozumienia zawartego przy „Okrągłym Stole" w sprawie reform politycznych. ${ }^{20}$ Do tekstu Konstytucji PRL-u dodano mię-

\footnotetext{
14 A. Antoszewski, R. Alberski, Sytemy wyborcze..., op. cit., s. 231.

15 Por. szerzej: R. Mojak, Transformacja ustroju politycznego w latach 1989-1997, (w:) W. Skrzydło (red.), Polskie prawo konstytucyjne, Lublin 2000, s. 69-93.

16 Stanowisko w sprawie reform politycznych, (w:) W. Salmonowicz (oprac.), Porozumienia Okrągłego Stołu, Olsztyn 1989, s. 8.

17 Por. szerzej: J. Wawrzyniak, Sejm i Senat w latach 1989-1997, (w:) J. Bardach (koordynator pracy), Dzieje Sejmu Polskiego, Warszawa 1997, s. 311.

18 Zob. szerzej: W. Sokolewicz, Kwietniowa zmiana Konstytucji, Państwo i Prawo 1989, z. 6, s. 3.

19 Ustawa z dnia 7 kwietnia 1989 roku o zmianie Konstytucji Polskiej Rzeczypospolitej Ludowej (Dz.U. Nr 19, poz. 101).

20 Przy „Okrągłym Stole” zawarto „kontrakt” polityczny obejmujący: 1) Stanowisko w sprawie reform politycznych; 2) Stanowisko w sprawie polityki społecznej i gospodarczej; 3) Stanowisko w sprawie pluralizmu związkowego. Akty te zyskały także miano umów społecznych; M. Kallas, A. Lityński, Historia ustroju i prawa Polski Ludowej, Warszawa 2003, s. 190.
} 
dzy innymi postanowienia dotyczące Senatu. Jej art. 2 ust. 1 otrzymał następujące brzmienie: „Lud pracujący sprawuje władzę państwową przez swych przedstawicieli, wybieranych do Sejmu, Senatu i do rad narodowych". ${ }^{21}$ Ponadto w tekście Konstytucji PRL-u znalazły się inne uregulowania odnoszące się do Senatu; zatrzymując się na najważniejszych przepisach dotyczących prawa wyborczego należy zwrócić uwagę na kilka kwestii.

W zakresie liczebności Senatu i długości jego kadencji wprowadzono następujący przepis: „Senat składa się ze 100 senatorów i jest wybierany na okres kadencji Sejmu”. ${ }^{22}$ Natomiast w art. 94 dodano ust. 2 w brzmieniu: „Wybory do Senatu są powszechne, bezpośrednie i odbywają się w głosowaniu tajnym". ${ }^{23}$ A zatem wśród przymiotników wyborczych nie została wymieniona zasada równości i proporcjonalności. Wynikało to z treści porozumienia zawartego przy „Okrągłym Stole”.

Wybory do Sejmu i Senatu w 1989 roku odbyły się w dwóch turach, według formuły większościowej. Warunkiem obsadzenia mandatu posła i senatora w pierwszej turze było uzyskanie bezwzględnej większości głosów w okręgu wyborczym. Odpowiedni przepis brzmiał następująco: „Za wybranych do Senatu w 2-mandatowym okręgu wyborczym uważa się dwóch kandydatów, którzy otrzymali kolejno największą liczbę głosów, pod warunkiem że każdy z nich otrzymał więcej niż połowę ważnych głosów. Za wybranych do Senatu w 3-mandatowym okręgu wyborczym uważa się trzech kandydatów, którzy otrzymali kolejno największą liczbę głosów, pod warunkiem że każdy z nich otrzymał więcej niż połowę ważnych głosów". ${ }^{24} \mathrm{Dla}$ obsadzenia mandatów w okręgach, w których kandydaci na posłów i senatorów nie uzyskali w pierwszej turze wymaganej, bezwzględnej większości ważnie oddanych głosów została przeprowadzona druga tura wyborów.

Wybory do Senatu, które przeprowadzono w 1991, 1993 i 1997 roku odbyły się na podstawie nowej ordynacji wyborczej ${ }^{25}$ według systemu większościowego, jednakże w miejsce większości bezwzględnej wprowadzono system oparty na większości względnej. Kwestia okręgów wyborczych i liczby senatorów wybieranych w nich nie uległa zmianie. „Do Senatu wybiera się 100 senatorów, według zasady większości, w okręgach wyborczych. Okręgiem wyborczym do Senatu jest obszar województwa. W okręgu wyborczym wybiera się 2 senatorów, a w okręgach obejmujących obszar województwa warszawskiego i województwa katowickiego wybiera się po 3 senatorów". ${ }^{26}$

Konstytucja Polskiej Rzeczypospolitej Ludowej uchwalona przez Sejm Ustawodawczy w dniu 22 lipca 1952 roku (tekst.jedn. Dz.U. z 1976 r. Nr 7, poz. 36 z późn. zm.).

Ibidem, art. 28 ust. 1.

Ibidem, art. 94 ust. 2.

Ustawa z dnia 7 kwietnia 1989 roku - Ordynacja wyborcza do Senatu Polskiej Rzeczypospolitej Ludowej (Dz.U. z 1989 r. Nr 19, poz. 103, art. 11).

Dz.U. z 1991 r., Nr 58, poz. 246, z późn. zm.

Ustawa z dnia 10 maja 1991 roku - Ordynacja wyborcza do Senatu Rzeczypospolitej Polskiej (Dz.U. z 1991 r. Nr 58, poz. 246 z późn. zm., art. 2). 
Według Konstytucji RP z 1997 roku: „Wybory do Senatu są powszechne, bezpośrednie i odbywają się w głosowaniu tajnym". ${ }^{27}$ Pominięcie zasady równości i proporcjonalności w przypadku wyborów do Senatu ,należy rozumieć tylko jako pozostawienie swobody regulacyjnej ustawodawcy zwykłemu, a w żadnym razie nie może ono dawać podstawy do wykładni a contrario, a więc do twierdzenia, że konstytucja wyklucza odniesienie równości i proporcjonalności do wyborów senackich". ${ }^{28}$ Tak więc w ordynacji wyborczej można z jednej strony wprowadzić rozwiązania, które będą oznaczać ustanowienie zasady równości, a z drugiej strony przyjąć dowolną formułę wyborczą. W tym miejscu warto jeszcze dodać, iż Konstytucja RP z 1997 roku (w przeciwieństwie do Małej konstytucji z 1992 roku $^{29}$ ) nie utrzymała wymogu powiązania Senatu ze strukturą istniejących województw.

Dnia 1 stycznia 1999 roku weszła w życie reforma terytorialna państwa, zgodnie z którą liczba województw uległa zmniejszeniu do szesnastu, co wymusiło wprowadzenie zmian w prawie wyborczym. Twórcy nowej ordynacji wyborczej dysponowali dużą swobodą przy kształtowaniu systemu wyborczego do Senatu, gdyż nie było konstytucyjnych przeszkód, aby wprowadzić wybory w stu jednomandatowych okręgach wyborczych czy system proporcjonalny. Ostatecznie dnia 12 kwietnia 2001 roku została uchwalona Ordynacja wyborcza do Sejmu i Senatu Rzeczypospolitej Polskiej. ${ }^{30}$ Nie zdecydowano się jednak na wprowadzenie istotnych zmian w przepisach regulujących sposób wyboru Senatu. Z utworzonych 40 okręgów wyborczych było wybieranych - na zasadzie większości względnej - od dwóch do czterech senatorów. ${ }^{31} \mathrm{~A}$ więc przedstawiciele do tej izby nadal byli wybierani w systemie większościowym z kilkumandatowych okręgów wyborczych. Ordynacja wyborcza z 2001 roku odeszła jednak od poprzednio funkcjonującego systemu, w którym każde województwo było okręgiem wyborczym do Senatu. ${ }^{32}$ Dokonała ona rozdziału mandatów senatorskich pomiędzy szesnaście województw, a następnie dwanaście z nich podzieliła na mniejsze okręgi. Liczba senatorów reprezentujących poszczególne województwa wynikała z jednolitej normy przedstawicielstwa. „Usunięto w ten sposób

27 Konstytucja Rzeczypospolitej Polskiej z dnia 2 kwietnia 1997 roku (Dz.U. z 1997 r. Nr 78, poz. 483 z późn. zm., art. 97 ust. 2).

28 L. Garlicki, Komentarz do art. 97, (w:) L. Garlicki (red.), Konstytucja Rzeczypospolitej Polskiej. Komentarz, Tom I, Warszawa 1999, s. 8.

29 „Senat składa się ze 100 senatorów wybieranych w województwach na okres kadencji Sejmu w wyborach wolnych, powszechnych, bezpośrednich, w głosowaniu tajnym"; Ustawa konstytucyjna z dnia 17 października 1992 roku o wzajemnych stosunkach między władzą ustawodawczą i wykonawczą Rzeczypospolitej Polskiej oraz o samorządzie terytorialnym (Dz.U. z 1992 r. Nr 84, poz. 426 z późn. zm., art. 3 ust. 2).

30 Dz.U. z 2001 r. Nr 46, poz. 499 z późn. zm.

31 Utworzono 22 okręgi dwumandatowe, 16 okręgów trzymandatowych i 2 okręgi czteromandatowe.

32 „W celu przeprowadzenia wyborów do Senatu tworzy się na obszarze poszczególnych województw okręgi wyborcze. W okręgu wyborczym wybiera się od 2 do 4 senatorów. Okręg wyborczy obejmuje obszar województwa lub jego części. Granice okręgu wyborczego nie mogą naruszać granic okręgów wyborczych tworzonych dla wyborów do Sejmu"; Ustawa z dnia 12 kwietnia 2001 roku - Ordynacja wyborcza do Sejmu Rzeczypospolitej Polskiej i do Senatu Rzeczypospolitej Polskiej (Dz.U. z 2001 r. Nr 46, poz. 499 z późn. zm., art. 191). 
jaskrawą nierówność, która istniała w czasie obowiązywania ordynacji wyborczych do Senatu z 1989 i 1991 roku". 33

Dnia 5 stycznia 2011 roku doszło do uchwalenia Kodeksu wyborczego, który określa między innymi zasady i tryb zgłaszania kandydatów, przeprowadzania oraz warunki ważności wyborów do Senatu RP. ${ }^{34}$ Istotną zmianą dotyczącą kreowania „drugiej izby" było wprowadzenie jednomandatowych okręgów wyborczych. ${ }^{35} \mathrm{Jak}$ wspomniano wcześniej, ustanowienie wyborów w okręgach jednomandatowych ma w Polsce duże grono zwolenników. W tym zakresie warto wspomnieć chociażby o działalności Ruchu Obywatelskiego na rzecz Jednomandatowych Okręgów Wyborczych. ${ }^{36}$ Jednakże zasadniczym celem postulatów obywatelskich jest wprowadzenie takiej formuły w wyborach do Sejmu RP.

W omawianym kontekście warto jeszcze zasygnalizować zagadnienie wyborów uzupełniających do Senatu. Wskazana procedura zazwyczaj nie wywołuje większego zainteresowania elektoratu, dlatego też frekwencja wyborcza jest bardzo niska. Dla zobrazowania przedmiotowego zagadnienia można wskazać, iż w głosowaniach, które odbyły się w trzech okręgach dnia 7 września 2014 roku frekwencja nie przekroczyła 10 procent. ${ }^{37} \mathrm{~W}$ związku z tym wydaje się celowe zgłoszenie wniosku de lege ferenda, aby zmiany w prawie wyborczym wyeliminowały (znacznie ograniczyły) konieczność przeprowadzania wyborów uzupełniających do „drugiej izby". W tym kontekście można przywołać chociażby propozycję, aby ustanowić instytucję ,zastępcy senatora”, która została zgłoszona w czasie rozpatrywania prezydenckiego projektu nowelizacji Ordynacji wyborczej do Sejmu i Senatu z 2001 roku ${ }^{38}$ Zgodnie z przedmiotową inicjatywą, na karcie wyborczej, obok nazwiska kandydata na senatora byłoby także wpisane nazwisko jego zastępcy. Wyborca oddawałby zatem głos jednocześnie na danego kandydata oraz na osobę, która (w razie niemożności sprawowania funkcji przez wybranego senatora) wchodziłaby automatycznie na jego miejsce. ${ }^{39}$ Innym sposobem rozwiązania zasygnalizowanego problemu mogłoby być ustanowienie mieszanej, większościowo-proporcjonalnej ordynacji wyborczej. Wówczas wybory uzupełniające byłyby przeprowadzane jedynie w przypadku wygaśnięcia mandatu senatora wybranego w jednomandatowym

S. Gebethner, Wybory do Sejmu i do Senatu. Komentarz do ustawy z dnia 12 kwietnia 2001 r. - Ordynacja wyborcza do Sejmu Rzeczypospolitej Polskiej i do Senatu Rzeczypospolitej Polskiej, Warszawa 2001, s. 279. Dz.U. z 2011 r., Nr 21, poz. 112 z późn. zm.

Ustawa z dnia 5 stycznia 2011 roku Kodeks wyborczy (Dz.U. z 2011 r. Nr 21, poz. 112 z późn. zm., art. 260). Jak możemy przeczytać na stronie internetowej Ruchu Obywatelskiego na rzecz Jednomandatowych Okręgów Wyborczych, wskazany ruch społeczny domaga się „wprowadzenia 460 jednomandatowych okręgów wyborczych (JOW) w wyborach do Sejmu RP z równym prawem do kandydowania dla wszystkich obywateli, niezależnie, czy są popierani przez partie czy startują samodzielnie"; O co walczymy?, jow.pl/abc/ (data dostępu: 06.01.2015 r.).

Obwieszczenie Państwowej Komisji Wyborczej z dnia 8 września 2014 roku o wynikach wyborów uzupełniających do Senatu Rzeczypospolitej Polskiej przeprowadzonych w dniu 7 września 2014 roku (Dz.U. z 2014 r., poz. 1208).

Druk nr 2545, Sejm RP IV kadencji.

Biuletyn nr 3862 z posiedzenia Komisji Ustawodawczej Sejmu RP IV kadencji, http://orka.sejm.gov.pl/Biuletyn. nsf/B4?Open (data dostępu: 06.01.2015 r.). 
okręgu, który nie był przypisany do żadnej listy kandydatów wybieranej zgodnie z zasadą proporcjonalności. W pozostałych wypadkach (wygaśnięcie mandatu obsadzonego w okręgu jednomandatowym, jak również z listy wyborczej), uzupełnienie składu Senatu następowałoby przez obsadzenie wakującego mandatu przez kolejnego kandydata $\mathrm{z}$ listy wyborczej zgłoszonej przez ten sam komitet, który zgłosił kandydaturę senatora, którego mandat wygasł.

\section{Praktyka wyborcza}

Odnosząc się do doświadczeń wyborczych S. Gebethner zaznaczył, iż „wybory do Senatu przynoszą wyraźne zniekształcenie woli wyborców przejawianej w akcie głosowania. W wyborach w 1997 r. na kandydatów AWS głosowało nie więcej niż 40\% wyborców, a w Senacie zasiadło 51\% senatorów AWS. Z kolei w 1993 r. 21\% głosowało na kandydatów SLD, co dało mu 37\% miejsc w Senacie". ${ }^{40}$ Kolejne wybory, które zostały przeprowadzone w 2001, 2005, 2007 i 2011 roku również potwierdziły poprawność przyjętej hipotezy badawczej. W 2001 roku Koalicyjny Komitet Wyborczy Sojusz Lewicy Demokratycznej-Unia Pracy w wyborach do Sejmu uzyskał poparcie $41,04 \%$ wyborców, natomiast w Senacie posiadał aż 75 przedstawicieli (na 100), spośród których tylko jeden uzyskał ponad 50\% głosów (Adam Gierek cieszył się poparciem niespełna $65 \%$ głosujących w okręgu wyborczym nr 31 Sosnowiec). Wybory do Senatu z lat 2005, 2007 i 2011 zostały całkowicie zdominowane przez kandydatów dwóch partii politycznych, tj. Platformy Obywatelskiej oraz Prawa i Sprawiedliwości. Dla przykładu w 2007 roku mandat uzyskał tylko jeden kandydat niezależny (Włodzimierz Cimoszewicz). Z kolei w 2011 roku, tj. po wprowadzeniu jednomandatowych okręgów wyborczych do Senatu, Platforma Obywatelska oraz Prawo i Sprawiedliwość zdobyły łącznie 94\% miejsc w „drugiej izbie” polskiego parlamentu. Zwycięska Platforma Obywatelska posiadała 63 senatorów, mimo iż zdecydowana większość kandydatów wskazanej partii politycznej nie uzyskała w swoich okręgach wyborczych poparcia rzędu 50\% (tylko 7 spośród senatorów PO cieszyło się poparciem bezwzględnej większości głosujących). ${ }^{41}$

Tym samy można sformułować tezę, iż większościowa formuła wyborcza przy zastosowaniu większości względnej skutkuje niereprezentatywnym składem Senatu. Największe ugrupowania polityczne (komitety wyborcze) mają w składzie „drugiej izby” zdecydowanie więcej przedstawicieli niż wynosi poparcie dla nich wyrażone w procentach. $Z$ drugiej strony należy wskazać, iż przyjęta formuła wyborcza doprowadziła do marginalizacji mniejszych partii politycznych i kandydatów niezależnych.

40 S. Gebethner, Wybory..., op. cit., s. XXIV.

41 Wszystkie dane odnoszące się do wyborów z lat 2001, 2005, 2007 i 2011 zostały zaczerpnięte ze strony internetowej Państwowej Komisji Wyborczej, http://pkw.gov.pl/wyniki-wyborow-i-referendow/wybory-i-referenda.html (data dostępu: 21.05.2015 r.). 


\section{Podsumowanie}

Od przywrócenia Senatu do polskiego systemu politycznego w 1989 roku jest on wybierany według formuły większościowej zgodnie z zasadą większości względnej (z wyjątkiem 1989 roku, gdy obowiązywała większość bezwzględna). Do wyborów z 2007 roku obowiązywały kilkumandatowe okręgi wyborcze, co uległo zmianie w 2011 roku, gdy na podstawie Kodeksu wyborczego ustanowiono 100 jednomandatowych okręgów wyborczych. W tym miejscu należy zaznaczyć, iż przyjęcie takiej formuły wyborczej pozostaje w zgodzie z postulatami znacznej części społeczeństwa, jednakże odnosi się przede wszystkim do wyborów sejmowych. W związku z tym możemy potraktować ustanowienie w 2011 roku okręgów jednomandatowych w wyborach do Senatu jako doskonałą okazję do przetestowania plusów i minusów takiego systemu w polskich realiach społeczno-politycznych. Biorąc pod uwagę dotychczasowe doświadczenia należy wskazać, że takie rozwiązanie stwarza duże problemy w zdobyciu mandatów przez mniejsze ugrupowania i kandydatów niezależnych, natomiast największe komitety wyborcze posiadają więcej miejsc $\mathrm{w}$ organie przedstawicielskim niż uzyskany poziom poparcia społecznego.

Podsumowując wydaje się celowe zgłoszenie wniosku de lege ferenda, aby w przyszłości zastanowić się nad ustanowieniem większościowo-proporcjonalnej ordynacji wyborczej do Senatu (do Sejmu takie rozwiązanie także jest warte rozważenia). ${ }^{42} \mathrm{~W}$ ten sposób można zredukować wady ordynacji większościowej (np. spore trudności w uzyskaniu mandatu przez mniejsze ugrupowania), jak również znacznie zredukować konieczność przeprowadzania wyborów uzupełniających do Senatu.

\section{BIBLIOGRAFIA}

Antoszewski A., przy współudziale R. Alberskiego, Systemy wyborcze, (w:) A. Antoszewski, R. Herbut (red.), Demokracje zachodnioeuropejskie. Analiza porównawcza, Wrocław 1997

Bingham Powell G., Jr., Wybory jako narzędzie demokracji. Koncepcje większościowe i proporcjonalne, Warszawa 2006

Garlicki L., Komentarz do art. 97, (w:) L. Garlicki (red.), Konstytucja Rzeczypospolitej Polskiej. Komentarz, Tom I, Warszawa 1999

Gebethner S., Wybory do Sejmu i do Senatu. Komentarz do ustawy z dnia 12 kwietnia 2001 r. - Ordynacja wyborcza do Sejmu Rzeczypospolitej Polskiej i do Senatu Rzeczypospolitej Polskiej, Warszawa 2001

Haman J., Demokracja. Decyzje. Wybory, Warszawa 2003

42 „Pouczające są doświadczenia z zastosowaniem takiego systemu wyborczego w Szkocji (większościowo-proporcjonalny system kompensacyjny - przyp. M.R.). W 1999 r. w wyborach do regionalnego parlamentu partia konserwatywna otrzymała poparcie $15,5 \%$ ogółu wyborców, lecz nie uzyskała żadnego mandatu bezpośrednio w którymkolwiek z 73 jednomandatowych okręgów. Dzięki zaś istnieniu mandatów wyrównawczych konserwatyści uzyskali 18 miejsc, tj. 14\% mandatów"; S. Gebethner, Wybory..., op. cit., s. XXV. 
Herbut R., System wyborczy, (w:) A. Antoszewski, R. Herbut (red.), Leksykon politologii, Wrocław 2002

Jackiewicz Z., Wpływ prawodawcy na wyniki wyborów, Państwo i Prawo 1995, nr 3

Kallas M., Lityński A., Historia ustroju i prawa Polski Ludowej, Warszawa 2003

Legutko R., Problemy demokratycznej partycypacji, (w:) J. Miklaszewska (red.), Polityka i świat wartości. Uczestnictwo obywateli w życiu społeczno-politycznym, Kraków 1998

Mojak R., Transformacja ustroju politycznego w latach 1989-1997, (w:) W. Skrzydło (red.), Polskie prawo konstytucyjne, Lublin 2000

Polarczyk K., Parlament polski na tle parlamentów innych państw. Analiza statystyczna, Raport nr 214 Biura Studiów i Ekspertyz Kancelarii Sejmu, Warszawa 2003

Rachwał M., Demokracja bezpośrednia w Polsce - fikcja czy rzeczywistość?, Przegląd Politologiczny 2010, nr 1

Rousseau J.J., Umowa społeczna, Warszawa 1966

Sokolewicz W., Kwietniowa zmiana Konstytucji, Państwo i Prawo 1989, nr 6

Stanowisko w sprawie reform politycznych, (w:) W. Salmonowicz (oprac.), Porozumienia Okrągłego Stołu, Olsztyn 1989

Uziębło P., Demokracja partycypacyjna. Wprowadzenie, Gdańsk 2009

Wawrzyniak J., Sejm i Senat w latach 1989-1997, (w:) J. Bardach (koordynator pracy), Dzieje Sejmu Polskiego, Warszawa 1997 


\section{EVOLUTION OF ELECTION LAW IN THE SENATE OF THE THIRD REPUBLIC OF POLAND}

This article presents evolution of the election law in the Senate of the Third Republic of Poland (1989-2011). The issue of electoral formula applied during election to the "second house" of the Polish parliament was given particular attention. For the purpose of the study, it was assumed that the electoral formula is the principle of transforming votes into seats.

Nowadays, three electoral formulas are applied - i.e. majority, proportionate and mixed. The majority formula is used for election to the Polish Senate; however, it was not until 2011 that one-seat constituencies were used (multi-seat constituencies were previously applied). It is worth emphasizing that the adopted legal solutions result in the necessity to hold by-elections, which receive little public attention. Therefore, the possibility of establishing a mixed formula ought to be taken into consideration in order to reduce negative impact of currently applied legal solutions, such as the difficulty in obtaining seats by smaller political parties and the need to hold by-elections.

Keywords: The Senate of the Third Republic of Poland, election law, electoral formula

Słowa kluczowe: Senat III RP, prawo wyborcze, formuła wyborcza 